\title{
Sustainable Use of Organic Solid Waste: A conceptual review through the Waste Pickers Organizations.
}

\author{
Sandoval Duarte, Ángela ${ }^{1}$, Segura Osuna, Jenny Alexandra² and Rodríguez Miranda, Juan Pablo ${ }^{3}$ \\ ${ }^{1}$ Estudiante de maestría en Desarrollo Sustentable y Gestión Ambiental. Facultad del Medio Ambiente y Recursos Naturales. \\ Universidad Distrital Francisco José de Caldas. Bogotá, Colombia.
}

${ }^{2}$ Docente de investigación tiempo completo. Corporación Universitaria Minuto de Dios, UNIMINUTO. Bogotá, Colombia.

${ }^{3}$ Profesor Titular. Grupo de Investigación AQUAFORMAT. Facultad del Medio Ambiente y Recursos Naturales. Universidad Distrital Francisco José de Caldas. Bogotá, Colombia.

ORCIDs: 0000-0003-3008-6135 (Jenny Alexandra), 0000-0002-3761-8221 (Juan Pablo)

\begin{abstract}
This manuscript considers various conceptual elements of the sustainable use of organic solid waste by including recycling organizations for this type of waste and their interrelation in integrated management, circular and solidarity economy, as well as the theoretical aspects of applied sustainability in this context.
\end{abstract}

Keywords: recyclers by trade, use, sustainability, organic waste.

\section{INTRODUCTION}

Globally, cities generate around 1.3 billion tons of solid waste per year (1.2 kg/inhabitant/day); This volume is estimated to increase to 2.2 billion tons ( $1.42 \mathrm{~kg} /$ inhabitant/day) by 2025 , with generation rates that will be more than double the current value in the next 20 years in the countries in development (Hoornweg, 2012). The global average composition of waste is still dominated by the organic fraction $(54 \%)$, followed by paper (16\%) and plastic (12\%) (Banco Mundial, 2011). Taking into account the scarcity of natural resources and the exponential growth of the population, the model for waste management is changing from the linear model of "extract, produce and dispose" to the model of the circular economy where the concept of 'waste' does not exists (Graziani, 2018).

In Latin America and the Caribbean, waste management has prevailed under the "collection and final disposal" scheme, leaving behind the use, recycling and treatment of waste (AIDIS-IDRC, 2006). In several countries in the region, landfills are still used and the practice of collection without classification and/or separation at the source continues. Additionally, there are a large number of recyclers working on the streets and in landfills, seeking to survive by taking advantage of mainly inorganic recyclable materials despite the risk to which they expose their health and physical integrity.

Additionally, the lack of infrastructure for the processing of organic waste has forced most of it to be sent to landfills, which intensifies problems such as leachate generation and the production of greenhouse gases. Despite this, there is a growing interest in the implementation of technologies for the treatment and use of organic solid waste, mainly due to the high levels of urbanization and the exhaustion of the useful life of the landfills currently used. In recent years, several countries in the region have adopted measures to address this situation, such as strengthening legal frameworks, increasing coverage of waste collection and closing of sanitary landfills (Graziani, 2018).

With the progressive increase in the generation of solid waste, it is necessary to redouble efforts in the area of management and recycling with the aim of reducing the pressure on natural resources and protecting the environment. As cited in (ONU Habitat, 2010), it is considered that Latin American cities need to transform their production models, moving from linear models based on extraction, production and waste to a circular economy model based on reduction, reuse and recycling. The transition to this type of model requires a process of strengthening inclusive recycling in order to generate comprehensive strategies that contribute to the reduction of waste and therefore to the fulfillment of environmental goals related to the preservation of natural resources, the reduction in energy consumption and carbon emissions. Recycling strengthens production schemes that are less intensive in natural resources, energy and pollution, since it promotes the use of waste as a raw material to obtain other products, thus requiring less energy than primary production.

\section{DEVELOPING}

In the context of waste, the principle of intergenerational equity implies that waste should be managed so that future generations do not encounter problems inherited from previous generations. Legacy waste, as well as contaminated sites and obsolete (hazardous) waste disposal plants, are examples of ways in which future generations can continue to bear the health, environmental and economic costs inherited from current bad practices.

The current lifestyle, with the triumph of the capitalist model, has caused waste to be produced at a higher rate than the planet 
can bear. Current consumption models encourage the purchase of consumer goods that, when produced, generate a series of residues that in most cases are not reintroduced into production systems. It is noteworthy that the materials with which these goods are built correspond to non-renewable resources and their accelerated use is causing the planet's reserves to be consumed at a very rapid rate.

Thus, for some authors, the most important thing is the controlled use of renewable natural resources, so that they are not depleted or degraded and this results in a reduction in their usefulness for future generations, keeping the inventories of natural resources constant (Sanchez, 2009). The global dimension of the problem has led to its increasing relevance in international documents and agreements. Thus, in the document "The future we want", document of the Rio +20 Conference on Sustainable Development, held in Rio de Janeiro in June 2012, paragraphs 215 to 219 are especially relevant for waste management (Real Ferrer, 2016). It is also noteworthy that waste management is present in several of the Sustainable Development Goals (SDGs 2016-2030) approved by the United Nations as a continuation of the Millennium Development Goals (ODM 2000-2015).

The Inter-American Development Bank (BID) created in 2009 a Water and Sanitation division of the Infrastructure and Environment Sector, corresponding to a group specialized in solid waste management, establishing a long-term program aimed at supporting the bank's activities in the sector and promoting initiatives such as the Regional Initiative for Inclusive Recycling (IRR) with projects in 14 countries in the region.

In the countries of the European Union, the regulation in force is Directive 2008/98/EC of the European Parliament and of the Council on waste and which repeals certain Directives (known as the Waste Framework Directive), which was the subject of Partial modification in 2015. The norm stresses that "the first objective of any waste policy must be to minimize the negative effects of waste generation and management on human health and the environment", taking as axes "Reduce the use of resources and favor the practical application of the waste hierarchy" (Real Ferrer, 2016).

Throughout the guideline, the obligations of the States are established with regard to adopting the "necessary measures to guarantee that all waste is subject to recovery operations" (art. 10.1); promoting "the reuse of products and activities for preparing for reuse, promoting the establishment and support of reuse and repair networks, the use of economic instruments, tender requirements, quantitative targets or other measures" (art .11.1); reuse and recycling (art. 11.2) or disposal (art. 12), among other areas.

\section{Benefits of Waste Management in the Dimensions of Sustainable Development}

Environmental. Making the most of solid waste, it is possible to reduce substantially the tons that are disposed of in sanitary landfills or other types of final disposal sites, since the final disposal of waste in poorly operated sites brings serious environmental problems related mainly to water pollution, due to leachates and atmospheric pollution from the generation of greenhouse gases, since organic waste represents $61 \%$ of the generation of greenhouse gases by GEI when they are buried in landfills as indicated in the document of the National Policy for the Integral Management of Solid Waste (CONPES, 2016).

Likewise, the use of organic materials manages to mitigate the emission of greenhouse gases, since, by using organic fertilizers as a substitute for synthetic fertilizers, it avoids that the gases derived from the application of synthetic fertilizers represented $13 \%$ of total emissions generated by agriculture, and are the fastest growing source of emissions, with an increase of 37\% since 2001 (Ministerio de Agricultura, 2014).

With the application of organic fertilizers, it contributes in the same way to the recovery of degraded soils, since they regulate the $\mathrm{pH}$ of the soils and thus encourage the creation of organic farming models. (Santos Calderon et al., 2016).

Social. One of the most affected populations in this matter is the people who live in areas adjacent to sanitary landfills or places of final disposal of solid waste, therefore, by making the most of the waste generated, the problems of odors, vectors are substantially minimized (flies, rodents, among others) and diseases that they can transmit, improving the quality of life of these inhabitants. On the other hand, it allows the inclusion of different communities and people to create and participate in exploitation projects; thus transforming values into groups committed to leading this type of initiative. (Santos Calderon et al., 2016).

Economic: The economic advantages that the utilization projects bring are not only to reduce production costs by replacing inputs with usable waste, which leads to minimizing external dependence on inputs and generating greater profit, since it provides greater sustainability and autonomy in the production process. On the other hand, this activity promotes the generation of employment, since it allows the inclusion and registration of waste recyclers, which generates an economic income for several families, thus reducing the unemployment rate (Santos Calderon et al., 2016).

\section{Circular Economy Concept}

This concept is related to the purposes of the research, since in Colombia the model that predominates in waste management corresponds to a linear economy model, which consists of extracting resources to produce products and the waste produced both in the production process, like those generated by the final consumer, are mainly discarded by technologies such as final disposal in sanitary landfill. This technology does not allow these wastes to be reintroduced into new production cycles, and as a result the wastes not only lose the potential to be used, but also generate a series of negative impacts on society and the environment. This vision is changing worldwide, due to the high environmental and social costs derived from this type of economy, and it is migrating towards circular type Figure 1. 


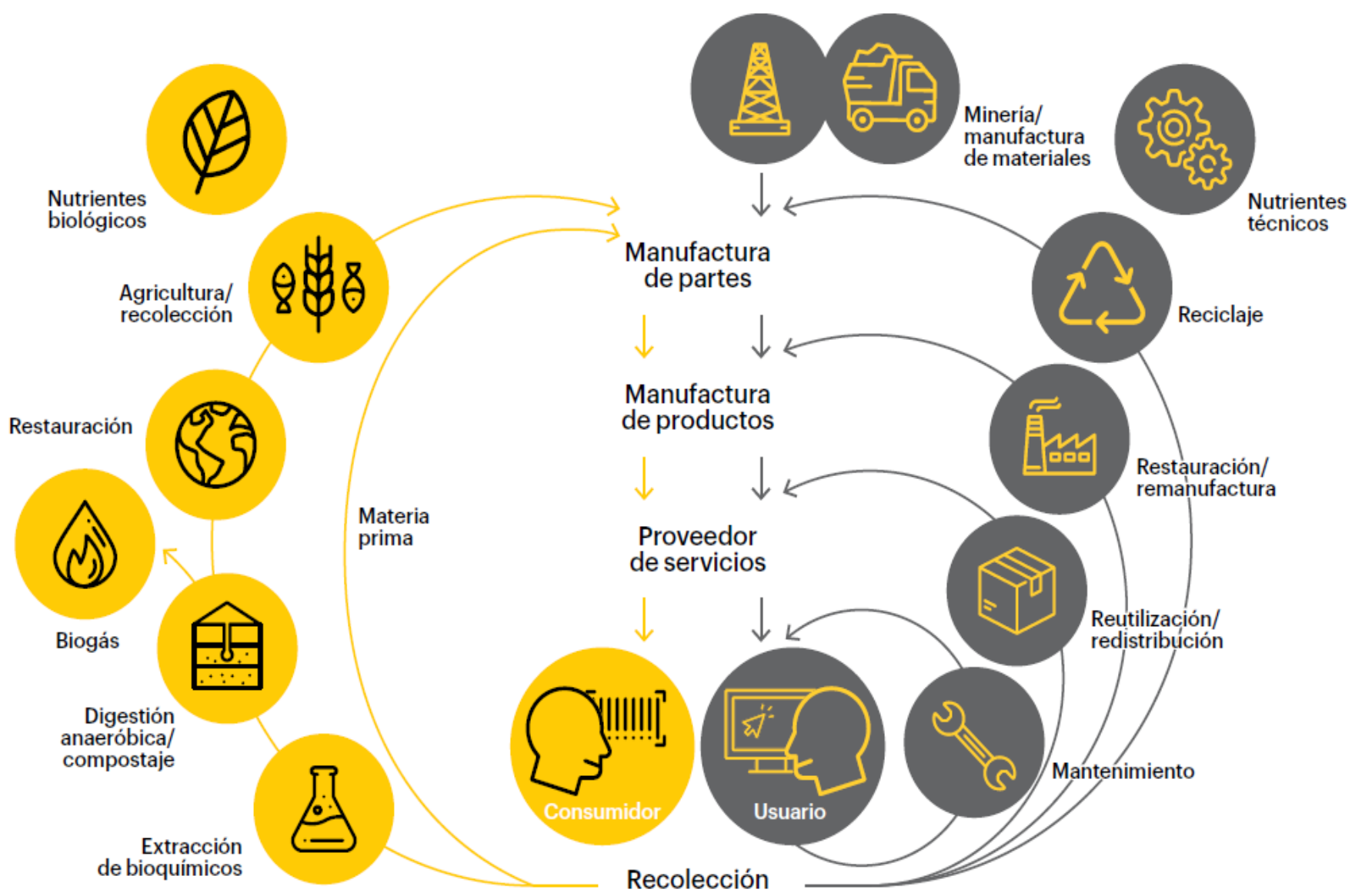

Figure 1: Circular economy in waste management

Source: Taken from Ellen MacArthur Foundation, 2013.

Since the nineteenth century, the period in which the first industrial revolution developed, a production model based on "extract, manufacture, consume and dispose" has been used, that is, extract natural resources such as mining, oil, gas, energy, water and forest. This reflects a perception of unlimited resources, without taking into account the environmental consequences that this model transfers to production models that actually exist in a context of limited resources (Foundation Robert Schuman, 2014).

The model scheme seeks through recycling, improvement and redesign of products and technology implementation; decrease and finally eradicate the generation of waste from consumption and production. Its main objective is to reduce pressure on the environment in different ways, increase social welfare and generate greater efficiency in industrial production. His focus is on the following topics:

$>\quad$ Efficiency Energy, through the use of renewable energy.

$>$ Redesign of materials based on technological advances. Eradication of waste by increasing recycling.

$>\quad$ Reduction of $\mathrm{CO}_{2}$ emissions and Greenhouse Gases.

$>\quad \square$ Creation of green jobs. $>\quad \square$ Minimize the use of toxic chemicals in economic activities.

$>\quad \square$ Sale of the use of the products.

$>\quad \square$ Conservation of the environment.

$>\quad \square$ Reduction and dependence on raw materials and energy.

$>\quad \square$ Waste recovery.

$>\quad \square$ Sustainable water treatment.

\section{Solidarity Economy}

This concept has been used by several countries that use the inclusion of vulnerable populations in waste management schemes in their management systems. This concept has been used for different economies of a community nature and arises from social organizations, which meet to solve a problem and obtain an economic benefit. In the case of recyclers by trade, due to the particularities of their social environment, the solidarity economy could be a reference concept for their transition to becoming companies that provide cleaning services. 
The Solidarity Economy claims the economy as a means and not as an end at the service of personal and community development, as an instrument that contributes to improving the quality of life of people and their social environment. A conception that bases its roots on an ethical and humanistic consideration of thought and economic activity, which places the person and the community at the center of development. In the center of his speech, he proposes incorporating into "the management of economic activity, the universal values that should govern society and the relations between all citizens: equity, justice, economic brotherhood, social solidarity and direct democracy" (De \& Elizalde, 2013).

These initiatives pay special attention to sectors of the population that are in a situation or at risk of social exclusion, turning companies into a potentially useful instrument for social integration and the fight against poverty. It is worth highlighting, in this area, the so-called insertion companies, an increasingly socially and legally recognized sector in different European regions. The characteristic that makes these companies different from the others is that they are transit structures that make it possible for later access to normalized employment to especially vulnerable groups, through the performance of a job and with special attention to their sociolabor accompaniment.

All solidarity, business, economic and financial initiatives committed to the following principles are recognized as solidarity economy companies:

1. Equality. Promote equality in relationships and satisfy in a balanced way the interests of all the protagonists in the activities of the company or organization.

2. Employment. Create stable employment, especially favoring the access of people in situation or at risk of social exclusion, ensuring each person working conditions and a decent remuneration, stimulating their personal development and assuming responsibilities.

3. Environment. Promote environmentally friendly actions, products and production methods.

4. Cooperation. Encourage cooperation rather than competition within and outside the organization. (Munain \& Celorio, 2007).

Consequently, this vision entails the development of a series of values and a repertoire of practices related to the empowerment of citizens and citizen organizations, the promotion of relationships based on cooperation and non-competitiveness, the development of democratic models in making decisions, ecological conservation, the generation of wealth and financial instruments in ethical conditions, the strengthening of the capacities of people and groups especially excluded, socioeconomic innovation at the service of local development, etc. (Elizaga, 2015).

\section{Inclusive recycling}

It is understood as the inclusion and recognition of the recycling union as an active and necessary part of the recycling activity and in the waste value chain in
Colombia. (MINVIVIENDA, 2014) see inclusive recycling as the use of solid waste from various aspects: social, economic, technical and environmental. Involving waste picker organizations and informal waste pickers in this process of transformation and renewal not only of solid waste but also of the recycling population; managing to promote an access route to a better quality of life in terms of health, social security, training, respect and support.

"Inclusive recycling" is understood as those waste management systems that prioritize recovery and recycling, recognizing and formalizing the role of recyclers as key actors in such systems. These systems are built through regulations and public policies, initiatives, programs and actions of the public and private sectors. Recycling with Inclusion represents a paradigm in the sustainable management of solid waste, which incorporates the concept of the environmental "3Rs" (Reduce, Reuse and Recycle), other "socio-economic 3Rs", namely: Differentiated waste collection, Recognition of the role of waste pickers and Remuneration for the service they provide.

\section{Integrated Management of Solid Waste}

This concept is articulated in the present investigation, since integrated waste management not only involves the technical issue, associated with the control of the generation, storage, collection, transfer and transportation, processing and disposal of solid waste; rather, it involves a series of steps and articulated institutions in the management of organic solid waste, responding to economic, environmental, social and technical principles.

Integrated solid waste management encompasses an articulated and interrelated set of regulatory, operational, financial, planning, administrative, social, educational, monitoring, supervision and evaluation actions for waste management, from generation to final disposal, in order to obtain environmental benefits, the economic optimization of its administration and its social acceptance, responding to the needs and circumstances of each locality and region (Marmolejo et al., 2005).

Integrated management is an interdisciplinary and under construction concept that can be understood from three levels that are closely related:

$>$ A first level refers to the stages of administration, that is, generation, conditioning, collection, transport, treatment and final disposal with energy recovery, from recyclables or biomass.

$>$ A second level in which the public administration must seek intersectorality, that is, the articulation of the different government sectors involved with the issue of solid waste, both in the municipal sphere and in relation to the provincial, regional and federal public spheres.

$>\square$ The third level that presupposes the involvement of multiple social agents in actions coordinated by the public power, that is, seeking inter-institutionality involving the government, the private sector and society. (Ginnther et al., 2006). 


\section{Waste Utilization Concept}

In the framework of Law 142 of 1994, this concept is recognized as a complementary activity of the public cleaning service, of the National Policy for the Management of Solid Waste of 2016 and Decree 1077 of 2017 modified by Decree 596 of 2016, where the use is defined as the activity "that includes the collection of usable waste, the selective transport to the sorting and use station or to the use plant, as well as its classification and weighing by the provider". It aims to take advantage of solid waste to achieve incorporation into the production cycle, as shown in figure 2 , in such a way as to guarantee its sustainability over time and reduce the environmental impact (Santos Calderon et al., 2016).

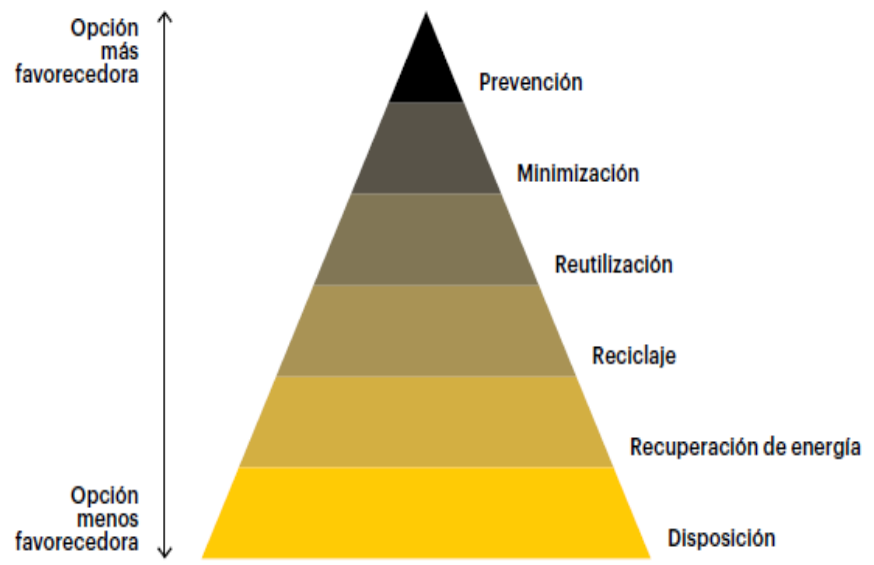

Figure 2: Model based on the use of waste

Source: Taken from Peterson, 2009.

\section{Purposes of waste utilization}

In this regard, Decree 1077 of 2015 sets out the seven specific purposes of harvesting as described below:

1. Rationalize the use and consumption of raw materials from natural resources.

2. Recover economic and energy values that have been used in the different production processes.

3. Reduce energy consumption in production processes that use recycled materials.

4. Increase the useful life of sanitary landfills by reducing the amount of waste finally properly disposed.

5. Reduce the flow and contaminating load of leachate in the sanitary landfill, especially when organic waste is used.

6. Reduce environmental impacts, both by demand and use of raw materials and by final disposal processes.

7. Guarantee the participation of waste pickers, in recovery and use activities, in order to productively consolidate these activities and improve their living conditions.
The current system as it is currently configured in Bogotá for organic solid waste, presents an untapped scheme like the one shown in Figure 3, however, the proposed model is based on the principles mentioned above, as shown in figure 4.

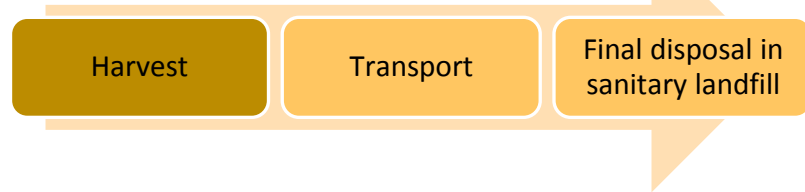

Figure 3: Current model of organic solid waste management in the district

Source: Self made

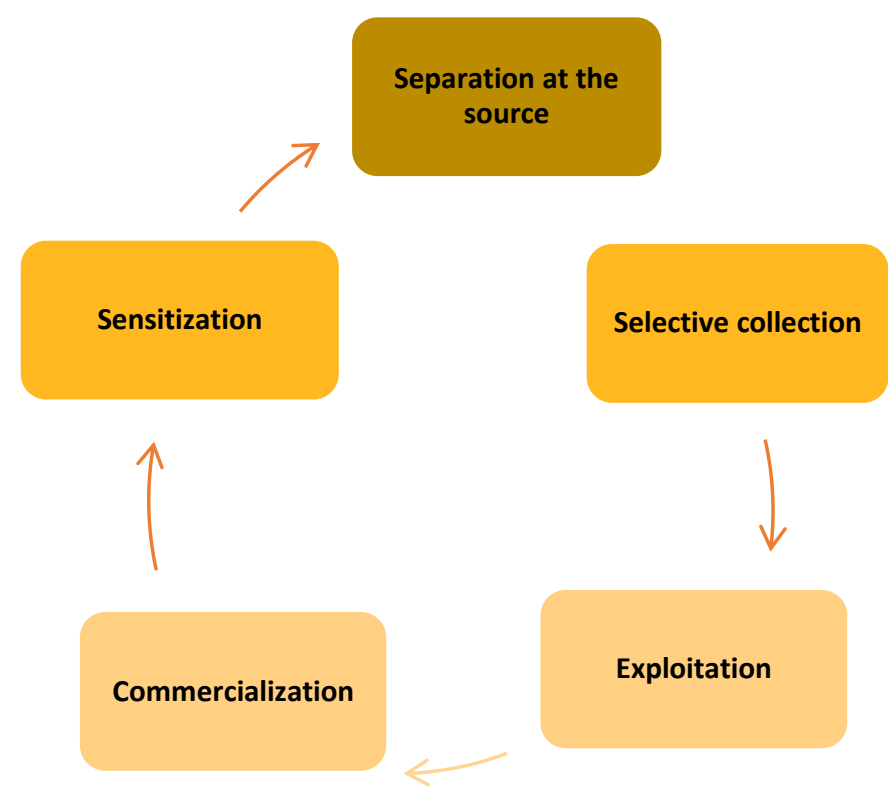

Figure 4: Circular model of use for organic waste

Source: Self made

\section{Definition of Organic Waste}

Organic solid wastes are all those that have carbon, nitrogen, oxygen and hydrogen in their structure and can be decomposed by the natural action of living organisms such as earthworms, bacteria and fungi. These can be vegetable peels, food residues, fruits, crop residues, tree leaves, among others, which are generated in kitchen activities, food consumption, gardening and plant pruning, fruit supply centers, vegetables or other products generated by the action of nature. (Mmaya, Vapsb, \& Dggirs, 2013).

\section{Characteristics of organic waste}

The Organic Fraction is the most unstable flow of waste, due to its high content in water (around $80 \%$ by weight) and in organic matter (carbohydrates, proteins and fats). 
International Journal of Engineering Research and Technology. ISSN 0974-3154, Volume 13, Number 8 (2020), pp. 2055-2066

(C) International Research Publication House. https://dx.doi.org/10.37624/IJERT/13.8.2020.2055-2066

Another important characteristic in terms of management is that the Organic Fraction has a fairly high but variable density, between $0.6-0.8 \mathrm{t} / \mathrm{m}^{3}$, which makes it weigh a lot and take up little space, generally presenting a low compactibility. (MAGRAMA (Ministerio de Agricultura, 2010).

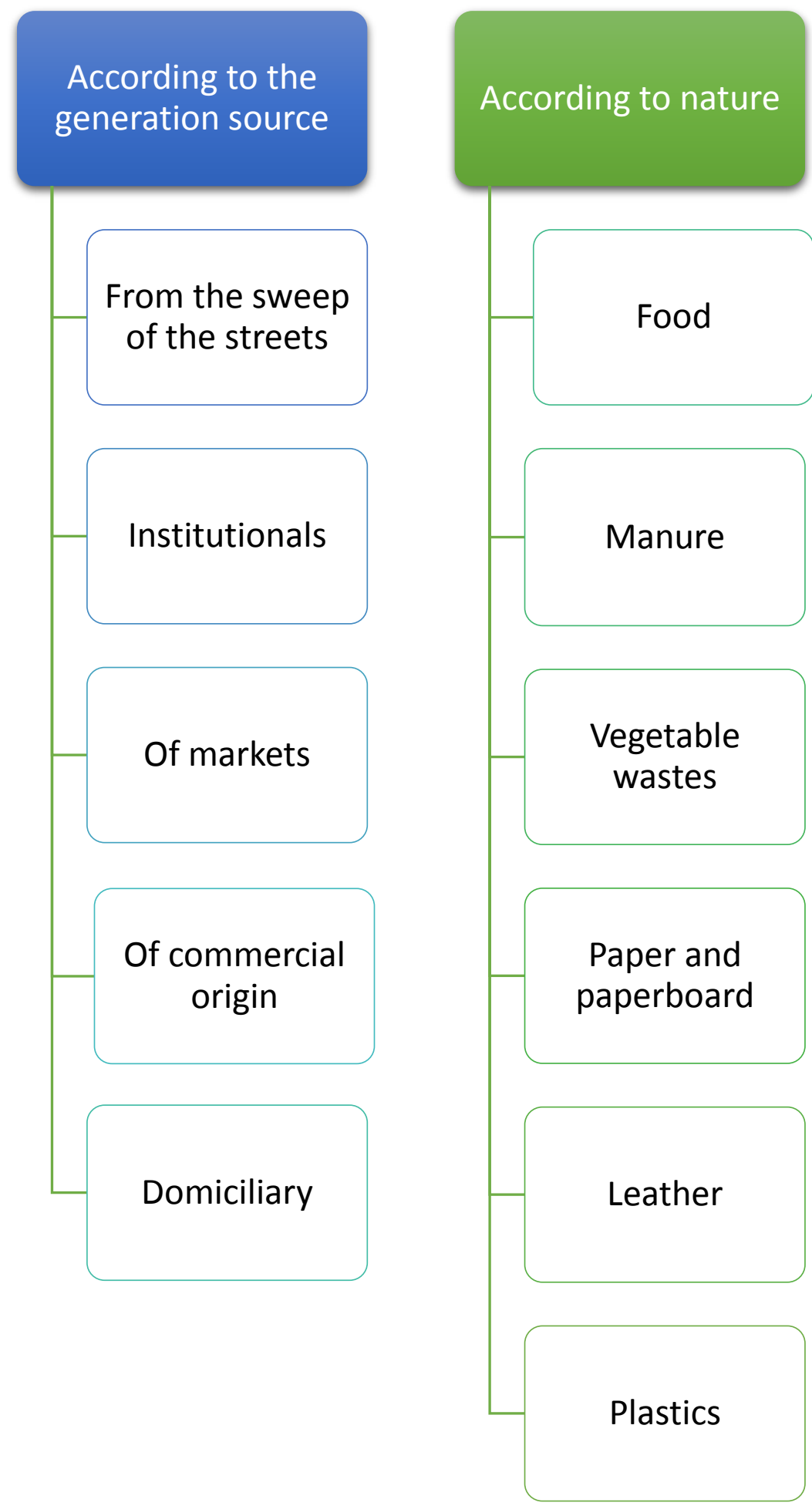

Figure 5: Organic waste classification

Source: Own elaboration based on Jaramillo and Zapata (2008). 
International Journal of Engineering Research and Technology. ISSN 0974-3154, Volume 13, Number 8 (2020), pp. 2055-2066

(C) International Research Publication House. https://dx.doi.org/10.37624/IJERT/13.8.2020.2055-2066

\section{Uses of organic waste}

Apparently these residues are the least desirable since they decompose quickly, with which come odors and other annoyances. But this type of waste can be given various uses as shown below. In houses, the first use given to them, without applying any process, is to feed domestic animals such as dogs, cats, chickens, pigs, among others. Table 1 summarizes some other uses that organic waste has as a profitable source of resources for the generation or transformation of other goods:

Table 1. Uses of organic solid waste

\begin{tabular}{|c|c|c|c|}
\hline Author(s) & Document & $\begin{array}{l}\text { Year of } \\
\text { publication }\end{array}$ & Use of RSO \\
\hline $\begin{array}{l}\text { Carlos Ariel Cardona Alzate, } \\
\text { Óscar Julián Sánchez Toro, } \\
\text { Julián Andrés Ramírez Arango, } \\
\text { Luis Eduardo Alzate Ramírez }\end{array}$ & $\begin{array}{l}\text { Biodegradation of organic waste } \\
\text { from market places. }\end{array}$ & 2004 & $\begin{array}{l}\text { - Biogas } \\
\text { - Composting } \\
\text { - Ethanol } \\
\end{array}$ \\
\hline $\begin{array}{l}\text { Krystle Danitza González } \\
\text { Velandia, Dayra Daza Rey, } \\
\text { Paola Andrea Caballero Amado } \\
\text { and Chadae Martínez González }\end{array}$ & $\begin{array}{l}\text { Evaluation of the physical and } \\
\text { chemical properties of organic } \\
\text { solid waste to be used in } \\
\text { papermaking }\end{array}$ & 2016 & - Recycled material paper \\
\hline Alejandra Nunez & $\begin{array}{l}\text { Use of organic waste from cafes } \\
\text { in animal feed }\end{array}$ & 2018 & - Animal food \\
\hline $\begin{array}{l}\text { Gladys Jaramillo Henao, Liliana } \\
\text { María Zapata Márquez }\end{array}$ & $\begin{array}{l}\text { Use of organic solid waste in } \\
\text { Colombia }\end{array}$ & 2008 & $\begin{array}{l}\text { - Composting: biofertilizers } \\
\text { and soil conditioners }\end{array}$ \\
\hline $\begin{array}{l}\text { Juan Remigio Coloma } \\
\text { Santamaria }\end{array}$ & $\begin{array}{l}\text { Recovery of organic waste and } \\
\text { its use in the manufacture of new } \\
\text { concretes }\end{array}$ & 2015 & $\begin{array}{l}\text { - Construction materials: } \\
\text { concretes, cement }\end{array}$ \\
\hline Jesus Maria Suarez Agudelo & $\begin{array}{l}\text { Use of solid waste from coffee } \\
\text { processing, in the Betania } \\
\text { Municipality of Antioquia: uses } \\
\text { and applications }\end{array}$ & 2012 & - Compost \\
\hline $\begin{array}{l}\text { Gilberto Iñiguez, Nalleli Acosta, } \\
\text { Liliana Martínez Javier Parra } \\
\text { and Orfil González }\end{array}$ & $\begin{array}{l}\text { Agave bagasse, tequila stillages, } \\
\text { biodegradation, composting }\end{array}$ & 2005 & $\begin{array}{l}\text { - Mattresses } \\
\text { - Bricks } \\
\text { - Compost } \\
\end{array}$ \\
\hline Mercado Castro, Donaldo & $\begin{array}{l}\text { Use of home organic waste in } \\
\text { obtaining useful materials of } \\
\text { environmental and } \\
\text { nanotechnological interest }\end{array}$ & 2016 & $\begin{array}{l}\text { - Nanotechnology elements } \\
\text { from waste orange peel and } \\
\text { matte }\end{array}$ \\
\hline
\end{tabular}

Source: Self made

\section{Composting phases}

According to Román, et. al. (2013), composting is divided into four different phases:

1. Mesophilic: in this initial phase the organic material starts from an ambient temperature and then rises to a temperature close to $45^{\circ} \mathrm{C}$. In this phase decomposition begins, the rise in temperature is caused by the action of microorganisms. This phase lasts between two and 8 days.
2. Thermophilic: in this phase the temperature is above $45^{\circ} \mathrm{C}$ and there are other microorganisms that are in action and follow the process of waste degradation, in this phase bacteria and fecal contaminants are destroyed, which is why it is done a cleaning process where other contaminating agents such as eggs and harmful bacteria are also destroyed.

3. Cooling: In this phase the temperature drops on average to $40{ }^{\circ} \mathrm{C}$, thus continuing the degradation of the material and showing fungi. This phase can take several weeks. 
4. Maturation: the organic material in this phase is at room temperature and lasts for months, while secondary reactions occur in which the product is the formation of humic and fulvic acids typical of the compost.

Bohórquez (2019) in his book shows how to carry out the composting process taking into account its bio-chemical properties and: temperature, oxygen, humidity, $\mathrm{pH}$, particle size and the carbon/nitrogen ratio. In the process, all these elements must be monitored so that the final product is as expected and complies with the characteristics that provide nutrients to the soil where they will be spread and applied.

Likewise, this author highlights that compost contributes many nutrients to the soil, which is why it is widely used in organic agriculture activities, guaranteeing the quality and conservation of the nutritional properties of crops. In addition, it allows plants to absorb more water and nutrients from the soil, thus producing more chlorophyll. Other benefits are the greater biomass and that crops such as tomato, onion, potato, among others, yield more, benefiting the grower who reduces costs through the reduction of water and fertilizer requirements, and even these plants are stronger and require less pesticides (Bohórquez, 2019).

\section{Internationally Composting}

Composting as a process to take advantage of organic solid waste is carried out worldwide, as well as in some Latin American countries, taking into account that they generate a large proportion of this waste, as illustrated by OPS et al. (2010). However, these entities in the report that present find that this composting process faces barriers, which have not allowed obtaining better results, among them:

- Lack of guides that are replicated and taken as an example.

- Lack of standards that are taken for the elaboration of the final product of the composting.

Likewise, if the benefits of this process were used, there would be a reduction in the levels of contamination caused by its decomposition, a reduction in leachate, all this in the end to have a product that serves as organic fertilizer, thus improving processes in agriculture and in the quality of the soils. As stated before, Chile has been an example in carrying out this process, Faundes (2011) and OPS et.al (2010).

In the case of México, Íñiguez, Rodríguez and Virgen (2006) point out that the degradation of the agave process can be exploited through a composting process. Said Agave comes from the Mexican tequila industry, which annually produces thousands of tons of bagasse and stillage in its liquid part. The organic waste generated by the Mexican tequila industry is not used in activities such as the manufacture of bricks or mattresses.

Taking into account the above, the composting process is useful to treat the waste generated in the production of tequila through agave, with this, an important nutrient for the soil can be produced, without adverse or toxic effects on the environment. In addition, by combining the agave bagasse with ash and urea, it was possible that the composting process was carried out more quickly, (Íñiguez, et. Al, 2006).

Another study for Mexico made by López, Serrato, Castelán and Avilés (2018) shows the differences between various methods of manure ventilation derived from livestock activities, which are very important given the participation and importance of livestock in that country. These wastes are highly polluting since they are often dumped into natural water sources or cultivated soils.

In Brazil, a study found that adding a series of nutrients to compost can vary the results of the product in the mushrooms production, this under controlled conditions, finding that in terms of the amount of product there were increases in the amount produced of mushrooms, but not in the size of theirs (Cunha, Pardo, Álvarez-Ortí, and Pardo-Giménez, 2018).

The processes where composting is carried out from residues with a high moisture component, as in the case of fruits and vegetables require a strategy for their control, which requires the use and installation of technologies (aeration with tumbling batteries or forced aeration), which is not always viable, especially in developing countries, (López et. al, 2018).

In another study, Delgado, Mendoza, González, Tadeo and Martín (2019) find that organic solid residues from poultry activity are highly polluting of air, water and soil, which is why its transformation into composting is recommended and its polluting effects. The authors show four possible processes: 1). manure plus straw, 2). chicken manure plus straw more ash, 3). chicken manure more straw more eggs and 4). chicken manure more straw more eggs more ash.

At the end, they conclude that, given the importance of poultry activity in Spain, this study carried out by the authors, but generates pollution given its content in phosphorus, nitrogen and sulfur. From the four possibilities analyzed, it was found that they have good properties in terms of nutrients for agricultural activities, so it can be used as organic fertilizer and crop substrate (Delgado, et. al. 2019).

In Brazil, studies have also been carried out where it is shown that compost is a great help in agriculture, Cunha, Pardo, Álvarez-Ortí and Pardo-Giménez, (2018) point out that compost when used in the land where the mushrooms are planted, when adding a special type of nutrients there were increases in harvested product, although no significant changes were observed in the size of the mushrooms.

Finally, in the case of Colombia Oviedo, Marmolejo and Torres (2014) show that through the increase in the number of times of turning and draining organic solid waste from the municipalities (which can have high degrees of humidity) it is possible to decrease the time required for the entire degradation process, which results in better results throughout the composting process. Likewise, the processes where composting is carried out from residues with a high humidity component, such as the case of fruits and vegetables, require a strategy for their control, which requires the use and installation of technologies (aeration with pile turning or forced aeration) which is not always feasible especially in developing countries. 
Suarez (2012) points out that $90.5 \%$ of the total weight of the coffee fruit is not used and, on the contrary, it is often disposed of in landfills, becoming a pollution agent, composting being a solution to said pollution problem. Another option that contributes to the environment is to carry out the process of removing the pulp from the fruit without using water, in order to reduce liquid waste in this process. Likewise, the composting process of the residues generated by the transformation of coffee would reduce the levels of contamination throughout the
Colombian coffee axis. The author points out that all the residues derived from poultry, aquaculture, fiquero, dairy and pig farming, among others, can be used to make compost.

From the above, the materials that in Latin America are the most used when treating organic waste for composting are presented, which contributes to the environment through the generation of a product that also allows to enrich the soil, see figure 6 :

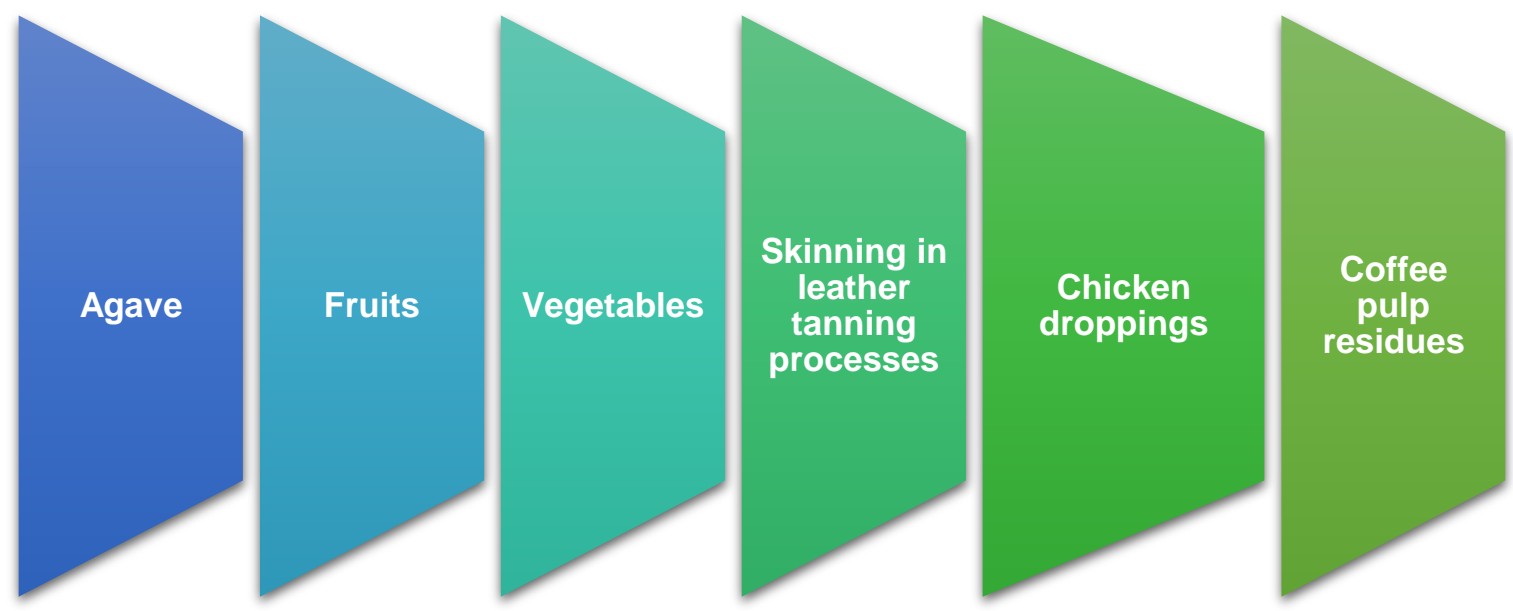

Figure 6. Some of the elements susceptible to compost

Source: Own elaboration with the authors consulted in this section

\section{CONCLUSIONS}

The general logic that guides European public policy in solid waste management is the waste hierarchy, which prioritizes prevention, minimization, reuse, recycling, other recoveries and final disposal as the last desirable option (EEA, 2015). The reduction in the amount of sanitary landfills in Europe is mainly due to the legislation that regulates the final disposal of organic waste in sanitary landfills by penalizing a cost per disposed ton. This economic disincentive explains a large part of the efforts made by European countries to adapt their waste management systems to current regulations (Directive 1999/31/EC del 26 de Abril 1999).

At the end of 2015 the European Union presented a package of measures for the circular economy. For this reason, it designed the "Close the circle" action plan and four legislative proposals, of which the proposal stands out consists of promoting and incentivizing the fertilizers production from biowaste largescale, based on the use of organic raw materials, which are transformed into fertilizers that are used in food production, aiming at a sustainable European agriculture (Arinas, 2016).

Composting is the most common biological treatment option in Europe; about $95 \%$ of current biological treatment operations. The leading countries are Germany, Spain and Switzerland. Where approximately 30 million tons of organic waste are selectively collected, composted or digested annually in almost 3,500 treatment plants (Graziani, 2018).

\section{ACKNOWLEDGMENT}

The authors thank the Francisco José de Caldas District University for the full support in the development of this research, this being a product generated from it.

\section{REFERENCES}

[1] Alianza Nacional para el Reciclaje Inclusivo. (2017). Guía para el fortalecimiento de Organizaciones de Recicladores, 36.

[2] Ariza, N. S. F. (2016). Manejo y separación de residuos sólidos urbanos. Análisis comparativo entre Madrid (España) y el distrito especial industrial y portuario de Barranquilla (Colombia)/Management and separation of urban solid waste comparative analysis between Madrid (Spain) and the industrial and port special district of Barranquilla (Colombia). Observatorio Medioambiental, 19, 197.

[3] Asociación Interamericana de Ingeniería Sanitaria y Ambiental-AIDIS; Centro Internacional de Investigaciones para el Desarrollo-IDRC (2006). Directrices para la gestión integrada y sostenible de residuos sólidos urbanos en américa latina y el caribe. Sao Paulo: AIDIS-IDRC.

[4] Bodova, E. (2017). Tools of environmental management and EU circular economy. MM Science Journal, 1, 1700-1706. 
International Journal of Engineering Research and Technology. ISSN 0974-3154, Volume 13, Number 8 (2020), pp. 2055-2066

(C) International Research Publication House. https://dx.doi.org/10.37624/IJERT/13.8.2020.2055-2066

[5] Castells, X. E. (2005). Tratamiento y valorización energética de residuos. Ediciones Díaz de Santos.

[6] Castro, F. (2012). Informe" Caracterización de la población recicladora de oficio en Bogotá. Bogota: Uaesp.

[7] Cohen, P., Ijgosse, J., y Sturzenegger, G. (2013). Desarrollo de planes de inclusión para recicladores informales en sitios de disposición final: una guía operativa. IDB/IRR.

[8] Consorcio NCU. (2017). Estudio técnico de la caracterización en la fuente de residuos sólidos generados en la Ciudad de Bogotá. Bogotá

[9] Corredor, M. (2010). El Sector Reciclaje en Bogotá y su Región: Oportunidades para los Negocios Inclusivos. Guia Sectorial FUNDES, 2, 60.

[10] Cortés, H. G., \& Peña, J. I. (2014). Modelo de desarrollo sustentable para su implementación en políticas y proyectos. Rev.Esc.Adm.Neg., EneroJuni(78), 40-55. https://doi.org/10.21158/01208160.n78.2015.1189

[11] Dourojeanni, A. (2000). Procedimientos de gestión para el desarrollo sustentable.

[12] Edalatpour, M. A., Mirzapour Al-e-hashem, S. M. J., Karimi, B., \& Bahli, B. (2018). Investigation on a novel sustainable model for waste management in megacities: A case study in tehran municipality. Sustainable cities and society, 36, 286301.

[13] Field, C. B., MacCracken, S., Mastrandrea, M. D., Levy, A. N., Bilir, T. E., Barros, V. R., ... \& Moreno, J. M. (2014). Cambio climático 2014 Impactos, adaptación y vulnerabilidad.

[14] Gallopin, G. (2008). Medio Ambiente Y Desarrollo.

[15] Garnett, K., Cooper, T., Longhurst, P., Jude, S., \& Tyrrel, S. (2017). A conceptual framework for negotiating public involvement in municipal waste management decision-making in the UK. Waste Management, 66, 210-221.

[16] Giinther, R., Maria, W., Grimberg, E., \& Ubal, W. (2006). Directrices para la gestión integrada y sostenible de residuos sólidos urbanos en America Latina y el Caribe.

[17] Graziani, P. (2018). Economía circular e innovación tecnológica en residuos sólidos Oportunidades en América Latina.

[18] Hénault-Ethier, L., Martin, J. P., \& Housset, J. (2017). A dynamic model for organic waste management in Quebec (D-MOWIQ) as a tool to review environmental, societal and economic perspectives of a waste management policy. Waste Management, 66, 196-209.

[19] Marconatto, D. A. B., Barin-Cruz, L., Pozzebon, M., \& Poitras, J. E. (2016). Developing sustainable business models within BOP contexts: mobilizing native capability to cope with government programs. Journal of cleaner production, 129, 735748.

[20] Marino, A. L., Chaves, G. D. L. D., \& dos Santos Junior, J. L. (2018). Do Brazilian municipalities have the technical capacity to implement solid waste management at the local level?. Journal of Cleaner Production, 188, 378-386.

[21] Medina, M. (1999). Reciclaje de desechos sólidos en América Latina. Frontera Norte, 11(21), 1-25.

[22] Mmaya, Vapsb, \& Dggirs. (2013). Guia para el aprovechamiento de residuos solidos organicos mediante compostaje y lombricultura. Ministerio de Medio Ambiente y Agua, primera ed(Bolivia).

[23] Lamboglia, R., Fiorentino, R., Mancini, D., \& Garzella, S. (2018). From a garbage crisis to sustainability strategies: The case study of Naples' waste collection firm. Journal of Cleaner Production, 186, 726-735.

[24] Lett, L. A. (2014). Las amenazas globales, el reciclaje de residuos y el concepto de economía circular. Revista argentina de microbiología, 46(1), 12.

[25] Lizaga, C. A. (2015). Economía Solidaria. Creative Commons Reconocimiento, 1-8.

[26] Pacheco, J. F., \& Contreras, E. (2016). Guía general para la gestión de residuos sólidos domiciliarios, 211.

[27] Padilla, A. J., \& Trujillo, J. C. (2018). Waste disposal and households' heterogeneity. Identifying factors shaping attitudes towards source-separated recycling in Bogotá, Colombia. Waste Management, 74, 16-33.

[28] Real Ferrer, G. (2016). Residuos y Sostenibilidad. El Modelo Europeo. La opción por la termovalorización, 29.

[29] Rebehy, P. C. P. W., Costa, A. L., Campello, C. A., de Freitas Espinoza, D., \& Neto, M. J. (2017). Innovative social business of selective waste collection in Brazil: Cleaner production and poverty reduction. Journal of Cleaner Production, 154, 462-473.

[30] Rodrigues, A. P., Fernandes, M. L., Rodrigues, M. F. F., Bortoluzzi, S. C., da Costa, S. G., \& de Lima, E. P. (2018). Developing criteria for performance assessment in municipal solid waste management. Journal of Cleaner Production, 186, 748-757.

[31] Rojas C, A., Yabar, H., Mizunoya, T., \& Higano, Y. (2018). The Potential Benefits of Introducing Informal Recyclers and Organic Waste Recovery to a Current Waste Management System: The Case Study of Santiago de Chile. Resources, 7(1), 18.

[32] Sáez, A., \& Urdaneta, J. A. (2014). Manejo de residuos sólidos en América Latina y el Caribe. Omnia 
International Journal of Engineering Research and Technology. ISSN 0974-3154, Volume 13, Number 8 (2020), pp. 2055-2066

(C) International Research Publication House. https://dx.doi.org/10.37624/IJERT/13.8.2020.2055-2066

Año, 20(3), 121-135.

[33] Santos Calderon, J. M., Mendoza Daza, J. M., López Murcia, J. D., Sierra Botero, M. E., \& Lozano Fonseca, A. (2016). Superintendencia de Servicios Públicos Domiciliarios: Informe Nacional de Aprovechamiento 2016, 1, 72 .

[34] Schamber, P. (2017). " Avances y desafíos para el reciclaje inclusivo: evaluación de 12 ciudades de América Latina y el Caribe".: The Economist Intelligence Unit (EIU), 2017, Nueva York. Estudios Socioterritoriales, 22, 0-0.

[35] Stephen, J. L., \& Periyasamy, B. (2018). Innovative developments in biofuels production from organic waste materials: A review. Fuel, 214, 623-633.

[36] Six, L., Velghe, F., Verstichel, S., \& De Meester, S. (2016). Sustainability considerations on the valorization of organic waste. In Biotransformation of agricultural waste and by-products(pp. 287-307).

[37] Oliveira, L. S., Oliveira, D. S., Bezerra, B. S., Pereira, B. S., \& Battistelle, R. A. G. (2017). Environmental analysis of organic waste treatment focusing on composting scenarios. Journal of cleaner production, 155, 229-237.

[38] Terraza, H. (2009). Lineamientos estratégicos del Banco Interamericano de Desarrollo para el sector de residuos sólidos. Banco Interamericano de Desarrollo. Washington (USA).

[39] Wan, C., Shen, G. Q., \& Choi, S. (2018). Differential public support for waste management policy: The case of Hong Kong. Journal of Cleaner Production, 175, 477-488.

[40] Bohórquez, W. (2019). El proceso de compostaje. Bogotá, Colombia. Universidad la Salle. Libro en línea. Recuperado de: https://ciencia.lasalle.edu.co/cgi/viewcontent.cgi?arti cle $=1071 \&$ context $=$ libros

[41] Cunha, D., Pardo, J. E., Álvarez-Ortí, M. y PardoGiménez, A. (2018). Desarrollo del cultivo de Agaricus bisporus en Brasil: suplementación del compost y utilización de híbridos. Revista Ciência Agronômica, 49(1), 122-129. Recuperado de: http://ccarevista.ufc.br/seer/index.php/ccarevista/artic le/view/4129

[42] Delgado, M., Mendoza, K., González, M., Tadeo, J. y Martín, J. (2019). Evaluación del proceso de compostaje de residuos avícolas empleando diferentes mezclas de sustratos. Revista Internacional de Contaminación Ambiental, 35(4), 965-977. Recuperado de: https://www.revistascca.unam.mx/rica/index.php/rica /article/view/RICA.2019.35.04.15

[43] El Tiempo (29 de abril de 2020). Vea en fotos cómo es la emergencia del relleno sanitario Doña Juana. El tiempo.

Recuperado https://www.eltiempo.com/bogota/relleno-donajuana-fotos-de-emergencia-por-un-derrumbe-debasura-489940

[44] Faundez, F. (2011). La Pintana: iniciativas para una comuna más sustentable. Recuperado de: http://www.plataformaurbana.cl/archive/2011/08/12/1 a-pintana-iniciativas-para-una-comuna-massustentable/

[45] Íñiguez, G., Rodríguez, R. y Virgen, G. (2005). Utilización de supbroductos de la industria tequilera. Parte 7. Compostaje de bagazo de agave y vinazas tequileras. Revista internacional de contaminación ambiental, 21(1), 37-50. Recuperado de: https://www.revistascca.unam.mx/rica/index.php/rica /article/view/22570

[46] Jaramillo Henao, G. Zapata Márquez, L. M. (2008). Aprovechamiento de los residuos sólidos orgánicos en Colombia. Recuperado de: http://bibliotecadigital.udea.edu.co/dspace/bitstream/ 10495/45/1/AprovechamientoRSOUenColombia.pdf

[47] López, S., Serrato, R., Castelán, O. y Avilés, F. (2018). Comparación entre dos métodos de ventilación en la composición química de compost de estiércoles pecuarios. Revista internacional de contaminación ambiental, 34(2), 263-271. https://www.revistascca.unam.mx/rica/index.php/rica /article/view/RICA.2018.34.02.07/46755

[48] Organización Panamericana de la Salud, OPS en conjunto con el Banco Interamericano de Desarrollo (BID), la Asociación Interamericana de Ingeniería Sanitaria y los gobiernos de los países intervinientes de América Latina (2010). Informe de la Evaluación Regional del manejo de residuos sólidos urbanos en América Latina y el Caribe (2010). Recuperado de: https://publications.iadb.org/publications/spanish/doc ument/Informe-de-la-evaluaci\%C3\%B3n-regionaldel-manejo-de-residuos-s\%C3\%B3lidos-urbanos-enAm\%C3\%A9rica-Latina-y-el-Caribe-2010.pdf

[49] Oviedo, E., Marmolejo, L. y Torres, P. (2014). Influencia de la frecuencia de volteo para el control de la humedad de los sustratos en el compostaje de biorresiduos de origen municipal. Revista internacional de contaminación ambiental, 30(1), 91$100 . \quad$ Recuperado de: https://www.revistascca.unam.mx/rica/index.php/rica /article/view/35074/40216

[50] Penagos, W., Adarraga, J., Aguas, D. y Molina, E. (2011). Reducción de los residuos sólidos orgánicos en Colombia por medio del compostaje líquido. Revista Ingeniare, (11). Recuperado de: http://ojsinvestigacion.unilibrebaq.edu.co/ojsinvestig acion/index.php/ingeniare/article/view/346/336

[51] Quintero, D. (2016). El papel de la gestión territorial en la ubicación de rellenos sanitarios. Caso de estudio: relleno sanitario Doña Juana, Bogotá, Colombia. Perspectiva Geográfica, 21(2), 251-276. DOI: 
International Journal of Engineering Research and Technology. ISSN 0974-3154, Volume 13, Number 8 (2020), pp. 2055-2066

(C) International Research Publication House. https://dx.doi.org/10.37624/IJERT/13.8.2020.2055-2066

https://doi.org/10.19053/01233769.5852

[52] Román, P., Martínez, M. M. y Pantoja, A. (2013). Manual de compostaje del agricultor: Experiencias en América Latina. Recuperado de: http://www.fao.org/3/a-i3388s.pdf

[53] Suarez, J. (2012). Aprovechamiento de los residuos sólidos provenientes del beneficio del café, en el municipio de Betania Antioquía: Usos y aplicaciones. Trabajo de grado Especialista en Gestión Integral de Residuos Sólidos y Peligrosos. Caldas-Colombia. Corporación universitaria Lasallista. Recuperado de: http://repository.lasallista.edu.co/dspace/bitstream/10 567/627/1/APROVECHAMIENTO_RESIDUOS_S OLIDOS_BENEFICIO_CAFE.pdf

[54] Unidad Administrativa Especial de Servicios Públicos, UAESP. (2020). Especiales UAESP Relleno Sanitario Doña Juana. Recuperado de: http://www.uaesp.gov.co/especiales/relleno/ 